\title{
The effect of superheated steam drying on physicochemical and microbial characteristics of Korean traditional actinidia (Actinidia arguta) leaves
}

\author{
Ah-Na Kim ${ }^{1}, \mathrm{Hee}^{-S u k ~ K o}{ }^{2}, \mathrm{Kyo}^{-}$Yeon Lee ${ }^{1}$, M. Shafiur Rahman ${ }^{1}$, Ho Jin Heo ${ }^{1}$, \\ Sung-Gil $\mathrm{Choi}^{3 *}$ \\ ${ }^{1}$ Division of Applied Life Science, Gyeongsang National University, Jinju 52828, Korea \\ ${ }^{2}$ Division of Rural Resources Division, Gyeongsangnam-do Agricultural Research and Extension Services, Jinju 52733, Korea \\ ${ }^{3}$ Division of Food Science and Technology (Institute of Agriculture and Life Scieces), Gyeongsang National University, \\ Jinju 52828, Korea
}

\section{과열증기 건조가 토종 다래순의 이화학적 및 미생물학적 특성에 미치는 영향}

\author{
김아나 ${ }^{1} \cdot$ 고희숙 $^{2} \cdot$ 이교연 ${ }^{1} \cdot$ 샤피어라만 ${ }^{1} \cdot$ 허호진 $^{1} \cdot$ 최성길 $^{3 *}$ \\ ${ }^{1}$ 경상대학교 응용생명과학부 응용생명과학전공, ${ }^{2}$ 경상남도농업기술원 농촌자원과, \\ 3경상대학교 농화학식품공학과( 농업생명과학연구원)
}

\begin{abstract}
The purpose of this study was to evaluate the effect of superheated steam drying on physicochemical and microbial characteristics of Korean traditional actinidia (Actinidia arguta) leaves. Actinidia leaves were dried at steam temperature of $350^{\circ} \mathrm{C}$ and oven temperature of $150^{\circ} \mathrm{C}$ for $40-200 \mathrm{sec}$. Moisture content and water activity decreased with increasing the drying time, while color values including $L$, $a$, and $b$ values and total color difference $(\Delta E)$ increased as drying time increased. The relationship between moisture content and water activity showed an exponential fit with high correlation vlaue $\left(\mathrm{R}^{2}=\mathbf{0 . 9 9 0 9}\right)$. Total phenolics and flavonoids content and antioxidant activity such as DPPH radical scavenging activity, ABTS radical scavenging activity, and FRAP assay of dried actinidia leaves increased with increasing the drying time up to $160 \mathrm{sec}$, but dramatically decreased at drying of 200 sec. The numbers of total areobic bacteria of leaves was not detected at drying time over $120 \mathrm{sec}$ and coliform of all the samples was not detected. As a results, the superheated steam was an very effective drying method of increase to the nutritional and sanitary quality of dried Korean traditional actinidia leaves.
\end{abstract}

Key words : actinidia leaves, superheated steam, drying, physicochemical characteristics, microbial characteristics

\section{서 론}

다래(Actinidia arguta Planch)는 우리나라 각처 산지에서 자라는 다래나무과(Acinidiaceae)에 속하는 낙엽활엽 덩굴 식물로 열매는 9월경에 완숙되어 과일로 섭취하며 어린

*Corresponding author. E-mail : sgchoi@gnu.ac.kr Phone : 82-55-772-1906, Fax : 82-55-772-1909

Received 31 January 2017; Revised 26 April 2017; Accepted 26 April 2017.

Copyright (c) The Korean Society of Food Preservation. All rights reserved.
다래순이나 잎은 4-5월에 채취하고 건조나물, 장아찌, 차 등의 형태로 활용한다(1). 다래순은 넓은 난형으로 가장자 리에 가는 톱니가 있는 것이 특징이며 특유의 깊은 맛과 약간 알싸한 맛으로 인해 기호도가 높다(2). 다래순을 포함 하여 대부분의 산채류는 고유의 독특한 향미와 질감 등 관능적 특성이 우수하고 수용성 식이섬유, 다양한 비타민 과 무기질 등 영양성분이 풍부할 뿐만 아니라 페놀성 화합 물 및 플라보노이드와 색소성분인 클로로필, 카로테노이드 등 생리활성 물질이 다량 함유된 저칼로리 식품이다 $(3,4)$. 따라서 산채류의 약리학적 가치가 새롭게 밝혀짐에 따라 건강지향식품 소재로 부각되고 있으며 이와 함께 항돌연변 
이성, 항종양 및 암세포에 대한 세포 독성, 간기능 개선, 항비만, 항균 효과 등의 건강기능적 특성을 규명하고자 하 는 연구가 활발히 이루어지고 있다(5,6). 다래순의 경우 높 은 산화방지 활성에 기인한 항당뇨 및 항비만 효과가 있는 것으로 보고되었다(7-9).

산채는 채취하는 시기가 제한적이며, 환경에 대한 낮은 적응성과 높은 수분함량으로 인해 미생물의 생육, 생화학 적 변화, 화학반응이 쉽게 일어날 수 있어 보존성이 낮고 중량에 비해 체적이 크기 때문에 저장 및 유통에 제한적이 다. 따라서 채취 후 대부분의 산채는 건조함으로써 저장성 을 향상시켜 연중 공급될 수 있도록 하며 이를 분말화하여 이용하거나 수침으로 복원시켜 섭취하게 된다 $(6,10)$. 현재 대부분 농가에서 천일건조법에 의해 건조나물이 생산되고 있지만 이는 균일한 제품을 생산하기 어렵고 장기간의 건조 시간이 소요되어 최종 수분함량 조절이 어려우며 광화학반 응에 의해 품질 저하 및 위생상 문제가 발생하기 쉽다(11). 이에 따라 산채류의 낮은 가공수준과 물량 및 가격변동은 불안정한 농가소득이 문제가 되고 있다(6). 따라서 산채 건조물의 산업 활성화를 위해서 열풍, 냉풍, 동결, 진공, 마이크로파, 원적외선 건조 등 많은 건조방법이 연구되고 있다(12). 열풍건조는 경제적이고 신속한 건조가 가능하지 만 피건조물의 급격한 수분손실에 의한 표면경화와 수축현 상에 의해 복원력이 낮고, 향미, 색, 영양성분의 손실 등의 문제점이 있다(13). 냉풍, 동결, 진공건조는 질감, 풍미, 색 조, 보존성, 복원성 등이 우수하지만 건조시간이 길고 비용 이 많이 드는 단점이 있어 이와 같은 문제점을 보완할 수 있는 건조공정에 대한 연구가 필요하다(14-16).

과열증기(superheated steam)는 포화수증기를 가열하여 생성되는 $100^{\circ} \mathrm{C}-400^{\circ} \mathrm{C}$ 사이의 온도를 가진 고온의 증기로 서, 식품의 건조, 살균, 가열조리 등 다양하게 이용되고 있다 (17). 과열증기처리는 기존의 건조공정에 비해 열 전달속도 가 빨라 건조시간이 짧고 처리 동안 무산소 환경이 조성되 기 때문에 다양한 생리활성 물질의 산화와 지방의 산패, 갈변현상, 이취 발생 등을 방지할 수 있다(18). 또한 고온의 증기가 식품 표면에 일정하게 분무되며 침투력이 강해 균일 하게 처리할 수 있고 증발 증기를 재활용함으로써 에너지를 절약할 수 있어 경제적이고 친환경적인 장점이 있다(17). 과열증기를 적용하여 이화학적 품질특성과 생리활성성분 의 변화를 연구한 소재로는 인삼(19), 양파(20), 마늘(21), 현미(22), 감자칩(23) 등이 있으나 산채의 건조에 이용한 연구는 전무한 실정이다.

따라서 본 연구에서는 과열증기처리 시간에 따른 토종 다래순의 수분함량 및 수분활성도와 그 상관관계를 검토하 여 건조 특성을 분석하고, 과열증기처리가 이화학적, 영양 학적, 미생물학적 특성에 미치는 영향을 규명하여 건조 다 래순 제조를 위한 과열증기처리의 적합성과 효율성을 검토 하였다.

\section{재료 및 방법}

재 료

본 실험에 사용한 토종 다래순(A arguta)은 2014년 5월에 수확하였으며 국립산림과학원으로부터 제공받아 $1 \%$ 염수 로 1 분간 침지한 후 흐르는 물에 세척하고 물기를 제거하여 $5^{\circ} \mathrm{C}$ 에서 보관하며 사용하였다. 연구에 사용된 시약 FolinCiocalteu's phenol reagent, gallic acid, diethylene glycol, rutin, 2,2-diphenyl-1-picryl-hydrazy(DPPH), 2,2'-azino- bis (3-ethylbenzthiazoline-6-sulfonic-acid)(ABTS), trpydyltriazine (TPTZ)는 Sigma-Aldrich(St. Louis, MO, USA)사에서 구입 하여 사용하였다.

\section{과열증기 건조방법}

과열증기건조 다래순은 과열증기장치(QF-5200C, Naomoto Corporation, Osaka, Japan)를 이용하였다(Fig. 1). 예비실험 을 통해 건조 공정에 적합한 증기온도 $350^{\circ} \mathrm{C}$, 오븐(내부)온 도 $150^{\circ} \mathrm{C}$, 증기량 $7.8 \mathrm{~m}^{3} / \mathrm{h}$ 을 최적 조건으로 설정하였고, 건조시간은 $40,120,160,200$ 초로 처리하였으며 과열증기 처리하지 않은 시료는 대조군로 하였다. 건조 방법으로는 먼저 과열증기 장치를 가열 조건에 맞춰 미리 예열시킨 후 채반에 다래순을 겹치지 않게 올려 이를 장치 내부에 고정시킨다. 상, 하단에 장착된 스팀 노즐을 통해 과열증기 가 분출되면서 다래순이 건조된다. 처리 직후 피건조물이 있는 채반을 꺼내어 상온에서 10 분간 방냉시킨 후 멸균용 기에 담아 보관하여 실험에 사용하였으며 총 폴리페놀 및 플라보노이드 함량과 항산화 활성 측정을 위해 동결건조를 실시하였다.

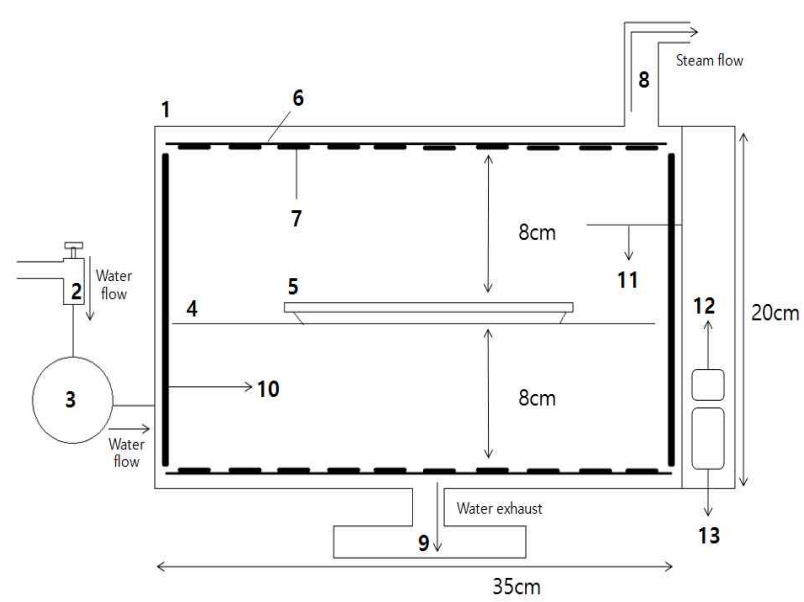

Fig. 1. Device structure and internal schematic diagram of superheated steam machine.

1 , chamber; 2, faucet; 3 , softener (for removing calcium, magnesium, certain other metal cation in hard water); 4 , tray; 5 , basket; 6 , heater; 7 , steam nozzle $\left(3.1-7.8 \mathrm{~m}^{2} \mathrm{~h}, 100-400^{\circ} \mathrm{C}\right)$; 8 , air exhaust port; 9 , water exhaust port; 10 , heating panel $\left(-350^{\circ} \mathrm{C}\right)$; 11 , heating wire; 12 , temperature controller; 13 , steam controller. 


\section{수분함량 및 수분활성도}

과열증기처리 시간에 따른 다래순의 수분함량과 수분활 성도의 변화를 측정하였다. 수분함량은 $105^{\circ} \mathrm{C}$ 상압가열건 조법(24)으로 측정하였다. 수분활성도는 수분활성도 측정 기(AQS-2, Nagy mess system, Gäufelden, Germany)를 이용 하였으며, 증류수(수분활성도=1.00)로 보정한 후 평형 수분 함량에 도달시켜 측정하였다. 또한 수분함량(x)과 수분활 성도(y)의 상관관계는 Microsoft Office Excel Program (Microsoft Corp., Roselle, IL, USA)을 이용하여 지수함수를 추정하였으며 관계식은 $\mathrm{y}=0.2032 \mathrm{e}^{6.1016 \mathrm{x}}$ 로 나타났다.

\section{색 도}

과열증기처리 시간에 따른 다래순의 색도 변화를 살펴보 기 위하여 표준백색판 $(\mathrm{L}=93.6, \mathrm{a}=0.31, \mathrm{~b}=0.32)$ 으로 보정된 색차계(Minolta CT-310, Minolta Co., Ltd., Osaka, Japan)를 이용하여 L(lightness, 명도), a(redness, 적색도) 및 $\mathrm{b}$ (yellowness, 황색도)값을 3회 반복 측정하였다(25). 또한 색차값 $(\Delta \mathrm{E})$ 은 아래 식에 대입하여 산출하였다.

$$
\begin{aligned}
& \Delta \quad \Delta L+\Delta a^{2}+\Delta b^{2} \\
& \Delta \mathrm{L}: \text { differences of lightness } \\
& \Delta \mathrm{a}: \text { differences of redness } \\
& \Delta \mathrm{b}: \text { differences of yellowness }
\end{aligned}
$$

\section{총 폴리페놀 및 플라보노이드 함량}

과열증기처리 시간에 따른 다래순의 총 페놀 및 플라보 노이드 함량을 측정하였으며, 동결건조한 시료를 $80 \%$ 메탄 올로 $200 \mathrm{rpm}$ 에서 24시간 동안 추출하여 여과 후 사용하였 다. 총 페놀 함량은 여과액 $1 \mathrm{~mL}$ 을 증류수 $9 \mathrm{~mL}$ 로 희석하고 $1 \mathrm{~mL}$ 의 Folin \& Ciocalteu's phenol reagent를 첨가하여 실온 암실에서 5 분간 방치한다. 그 후 $7 \%$ sodium carbonate 10 $\mathrm{mL}$ 과 증류수 $4 \mathrm{~mL}$ 을 첨가하여 총량을 $25 \mathrm{~mL}$ 으로 하였다. 이를 실온 암실에 2 시간 동안 방치한 다음 분광광도계 (UV-1800, Shimadzu Corporation, Kyoto, Japan)를 이용하여 $760 \mathrm{~nm}$ 에서 흡광도를 측정하였으며, 총 페놀 함량은 $\mathrm{g}$ gallic acid equivalent(GAE)/kg dry weight(DW)로 나타내었 다(26).

총 플라보노이드 함량은 $\mathrm{AOAC}$ 에서 공인된 방법을 약간 수정한 Chae 등(27)의 방법에 따라 측정하였다. 여과액 100 $\mu \mathrm{L}$ 과 $90 \%$ diethylene glycol $900 \mu \mathrm{L}$ 를 혼합한 후 $1 \mathrm{~N} \mathrm{NaOH}$ $20 \mu \mathrm{L}$ 를 첨가하여 $37^{\circ} \mathrm{C}$ 항온수조에 20 분 동안 반응시켰다. 이를 분광광도계(UV-1800, Shimadzu Corporation, Kyoto, Japan)를 이용하여 $420 \mathrm{~nm}$ 에서 흡광도를 측정하였으며, 총 플라보노이드 함량은 g rutin equivalent(RE)/kg DW로 나타 내었다.

\section{항산화 활성}

과열증기처리 시간에 따른 다래순의 항산화 활성을 측정
하였으며, 동결건조한 시료를 $80 \%$ 메탄올로 $200 \mathrm{rpm}$ 에서 24 시간 동안 추출하여 여과 후 사용하였다. $\mathrm{DPPH}(2,2-$ diphenyl-1-picrylhydrazyl) 라디컬 소거 활성은 Blois(28)의 방법을 변형하여 실험을 진행하였다. $100 \mathrm{~mL}$ 의 에탄올에 $8 \mathrm{mg}$ 의 DPPH를 용해시켜 제조하였다. 여과액 $0.1 \mathrm{~mL}$ 은 $\mathrm{DPPH}$ 용액(OD:1.000) $0.9 \mathrm{~mL}$ 과 혼합하여 실온 암실에서 30 분간 방치 후 분광광도계(UV-1800, Shimadzu Corporation, Kyoto, Japan)를 이용하여 $517 \mathrm{~nm}$ 에서 흡광도를 측정하였 으며, 이를 $\mathrm{g}$ butylated hydroxyanisole equivalent(BHAE)/Kg $\mathrm{dw}$ 로 나타내었다.

ABTS(2,2'-azino-bis(3-ethylbenzthiazoline-6-sulfonic acid)) 라디컬 소거능은 $\operatorname{Re}$ 등(29)의 방법을 변형하여 실험 을 진행하였다. ABTS 용액은 $7 \mathrm{mM}$ ABTS diammonium salt와 $2.45 \mathrm{mM}$ potassium persulphate를 혼합 후 실온 암실 에서 16 시간 동안 방치하여 제조하였다. 여과액 $20 \mu \mathrm{L}$ 와 ABTS 용액 $980 \mu \mathrm{L}$ 를 혼합 후 실온 암실에서 6분 동안 방치 한 후 분광광도계(UV-1800, Shimadzu Corporation, Kyoto, $\mathrm{Japan}$ )를 이용하여 $734 \mathrm{~nm}$ 에서 흡광도를 측정하였다. ABTS 라디컬 소거능은 g ascorbic acid equivalent(AAE)/Kg $\mathrm{dw}$ 로 나타내었다.

FRAP(ferric ion reducing antioxidant power) 측정은 Benzie와 Strain(30)의 방법을 변형하여 실험을 진행하였다. 즉 $300 \mathrm{mM}$ sodium acetate buffer(pH 3.6)와 $40 \mathrm{mM} \mathrm{HCl}$ 로 용해시킨 $10 \mathrm{mM}$ trpydyltriazine(TPTZ), $20 \mathrm{mM} \mathrm{FeCl} \cdot 6 \mathrm{H}_{2} \mathrm{O}$ 을 제조하였고, 이를 각각 $10: 1: 1(\mathrm{v} / \mathrm{v} / \mathrm{v})$ 비율로 혼합하여 FRAP 용액을 제조하였다. 여과액 $50 \mathrm{uL}$ 와 FRAP 용액 $1.5 \mathrm{~mL}$ 를 혼합 후 실온 암실에서 30 분간 방치한 후 분광광 도계(UV-1800, Shimadzu Corporation, Kyoto, Japan)를 이용 하여 $593 \mathrm{~nm}$ 에서 흡광도를 측정하였다. FRAP 환원력은 $\mathrm{g} \mathrm{Fe}(\Pi) / \mathrm{kg} \mathrm{DW}$ 로 나타내었다.

\section{미생물 수 측정}

과열증기처리 시간에 따른 다래순의 일반세균과 대장균 군 수를 측정하였다. 시료를 멸균된 stomacher bag에 넣은 후 $0.85 \%$ 멸균생리식염수로 10 배 희석하여 stomacher로 2 분간 균질화하였다. 이후 10 배씩 단계별 희석하여 시료를 준비하였으며 희석한 시료 $1 \mathrm{~mL}$ 를 일반세균 Petrifilm $^{\mathrm{TM}}$ aerobic count plate(3M Company, St. Paul, MN, USA)에 접종하였다. 배지를 $35^{\circ} \mathrm{C}$ 에서 48 시간 배양하여 30-300개 사이의 colony 수를 측정하여 시료 $1 \mathrm{~g}$ 당 colony-forming units(CFU)을 $\log$ 단위로 환산하여 표시하였다. 대장균군은 위의 방법과 동일하게 단계 희석하여 Petrifilm ${ }^{\mathrm{TM}}$ coliform count plate(3M Company, St. Paul, MN, USA)에 접종하였고 $35^{\circ} \mathrm{C}$ 에서 24 시간 배양 후 기포를 가진 red colony만을 확인 하였다.

\section{통계분석}

실험 결과는 3회 반복 실험하여 얻어진 평균 \pm 표준편차 
로 나타내었고, 통계처리는 Window용 SAS 9.4 version (SAS Institute Inc., Cary, NC, USA)을 이용하여 $\mathrm{p}<0.05$ 수준 에서 분산분석(analysis of variance) 하였으며, Duncan의 다 중범위 검정법(Duncan's multiple range test)으로 유의성을 검증하였다.

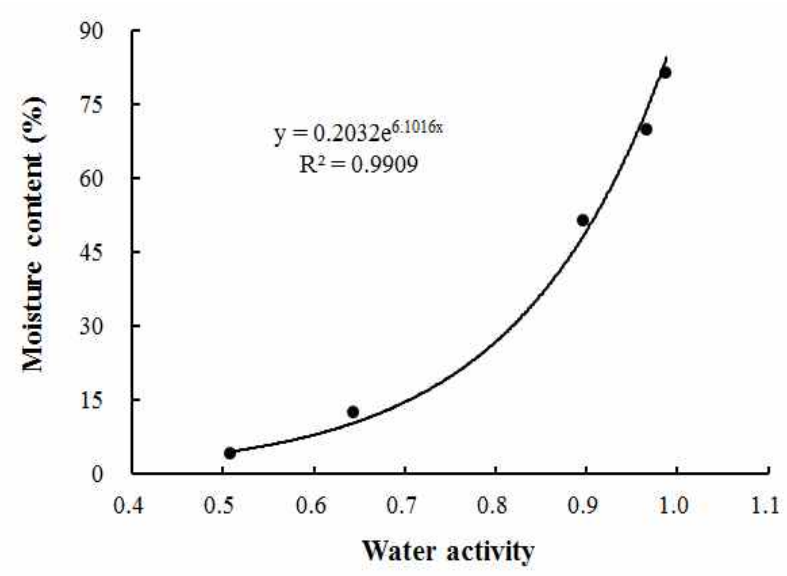

Fig. 2. Correlation between moisture content and water activity of Kor ean traditional actinidia leaves at oven temperature of $150^{\circ} \mathrm{C}$ and steam temperature of $350^{\circ} \mathrm{C}$ for $40-200 \mathrm{sec}$.

\section{결과 및 고찰}

\section{수분함량 및 수분활성도}

증기온도 $350^{\circ} \mathrm{C}$ 에서 과열증기처리 시간에 따른 다래순 의 수분함량과 수분활성도 결과는 Table 1 과 같다. 처리 전 대조군의 수분함량과 수분활성도는 각각 $81.18 \%, 0.99$ 로 나타났으며 처리 시간이 길어질수록 수분함량과 수분활 성도 모두 유의적으로 감소하여 200초 처리 시 각각 $3.94 \%$ 와 0.51 로 나타났다. 일반적으로 건조식품은 수분함량이 $10 \%$, 수분활성도 0.6 내외인 것을 말하며(31,32), 다래순은 과열증기건조 시간 120 초까지 $51.3-81.2 \%$ 의 수분함량과 $0.90-0.99$ 의 수분활성도를 가지므로 건조가 불충분한 것으 로 판단되어 160 초 이상 처리가 건조 다래순 제조에 적합한 것으로 사료된다. 과열증기 건조는 과열증기와 피건조물 사이의 직접적인 접촉에 의해서 일어나며 건조 매체인 과열 증기가 수분 증발을 위한 열을 피건조물에 제공함으로써 건조되는 원리이다(17). Choi 등(23)은 감자 절편에 과열증 기온도 $120-220^{\circ} \mathrm{C}$, 처리 시간 $2-10$ 분으로 건조하였을 때 처리 온도 및 시간이 길어질수록 수분함량이 유의적으로 감소하는 것으로 나타났다. 또한 Rhim과 Hwang(11)은 $50-105^{\circ} \mathrm{C}$ 온도에서 열풍 건조 시 100 분 이상 건조하였을 때 모든 산채류의 수분함량이 $5 \%$ 이하로 감소하였다고 보 고하였으며, Moreira(33)은 열 풍건조보다 과열증기건조의 건조율이 높은 것으로 보고하였다. 따라서 기존의 열풍건 조보다 과열증기건조 방법은 시료의 건조시간을 크게 단축
시킬 수 있을 것으로 판단된다. 과열증기건조 시간에 따른 수분함량과 수분활성도의 관계는 Fig 2 와 같으며, 상관관계 를 나타내는 결정계수는 0.99 로 높은 상관성을 가지는 것으 로 나타났다. 수분함량과 수분활성도의 관계를 지수함수로 나타냄으로써 측정하지 않은 범위의 수분활성도에 해당되 는 수분함량을 예측할 수 있다(34,35).

Table 1. Moisture content and water activity of Korean traditional actinidia leaves dried at oven temperature of $150^{\circ} \mathrm{C}$ and steam temperature of $350^{\circ} \mathrm{C}$ for $40-200 \mathrm{sec}$

\begin{tabular}{ccc}
\hline $\begin{array}{c}\text { Drying time } \\
(\mathrm{sec})\end{array}$ & Moisture content $(\%)$ & Water activity \\
\hline Control & $81.18 \pm 1.27^{1 / 22)}$ & $0.99 \pm 0.01^{\mathrm{a}}$ \\
40 & $69.79 \pm 2.55^{\mathrm{b}}$ & $0.97 \pm 0.00^{\mathrm{ab}}$ \\
120 & $51.30 \pm 2.91^{\mathrm{c}}$ & $0.90 \pm 0.04^{\mathrm{b}}$ \\
160 & $12.41 \pm 0.37^{\mathrm{d}}$ & $0.64 \pm 0.07^{\mathrm{c}}$ \\
200 & $3.94 \pm 0.96^{\mathrm{e}}$ & $0.51 \pm 0.02^{\mathrm{d}}$ \\
\hline
\end{tabular}

${ }^{1)}$ All values are mean $\pm \mathrm{SD}(\mathrm{n}=3)$.

${ }^{2)}$ Different letters superscript indicate in the same column that means are significantly different $(p<0.05)$ by Duncan's test.

색 도

증기온도 $350^{\circ} \mathrm{C}$ 에서 과열증기처리 시간에 따른 다래순 의 색도 결과는 Table 2 와 같다. 대조군의 $\mathrm{L}$ (명도), $\mathrm{a}$ (적색 도), b(황색도) 값은 각각 $29.9,-0.63,2.07$ 으로 나타났으며, 처리 시간이 증가할수록 모든 값이 유의적으로 증가하는 경향을 나타내어 200 초 처리한 다래순은 각각 $38.5,0.20$, 6.91 으로 나타났다. 이에 따라 과열증기처리 시간이 길어질 수록 전반적인 색차값 $(\Delta \mathrm{E})$ 또한 증가하는 것으로 나타났다. Arslan과 Ozcan(36)은 savory leaves을 열풍 건조하였을 때 $\mathrm{L}$ 값이 감소하고 $\mathrm{a}$ 값과 $\mathrm{b}$ 값이 증가한다고 보고하였으며, Arslan 등(37)은 페퍼민트를 천연, 오븐, 마이크로웨이브 건조 시 모든 처리군에서 $\mathrm{L}$ 값은 감소하고 $\mathrm{a}$ 값이 증가한다 고 보고하였다. $\mathrm{Oh}$ 등(38)은 과열증기온도 $330^{\circ} \mathrm{C}$ 와 $350^{\circ} \mathrm{C}$ 에 서 닭 가슴살을 가열했을 때 처리 시간이 길어질수록 $\mathrm{b}$

Table 2. Color values and total color difference $(\Delta \mathrm{E})$ values of Korean traditional actinidia leaves dried at oven temperature of $150^{\circ} \mathrm{C}$ and steam temperature of $350^{\circ} \mathrm{C}$ for $40-200 \mathrm{sec}$

\begin{tabular}{ccccc}
\hline \multirow{2}{*}{$\begin{array}{c}\text { Drying time } \\
(\mathrm{sec})\end{array}$} & \multicolumn{3}{c}{ Color values } & \multirow{2}{*}{$\Delta \mathrm{E}$} \\
\cline { 2 - 4 } & $\mathrm{L}$ & $\mathrm{a}$ & $\mathrm{b}$ & \\
\hline Control & $29.93 \pm 2.23^{1)(2)}$ & $-0.63 \pm 0.07^{\mathrm{b}}$ & $2.07 \pm 0.20^{\mathrm{d}}$ & - \\
40 & $33.60 \pm 1.69^{\mathrm{b}}$ & $-0.60 \pm 0.26^{\mathrm{b}}$ & $2.43 \pm 0.69^{\mathrm{d}}$ & $11.12 \pm 2.37^{\mathrm{b}}$ \\
120 & $36.19 \pm 2.69^{\mathrm{ab}}$ & $-0.27 \pm 0.36^{\mathrm{ab}}$ & $3.92 \pm 0.16^{\mathrm{c}}$ & $13.36 \pm 3.38^{\mathrm{b}}$ \\
160 & $38.23 \pm 1.63^{\mathrm{a}}$ & $-0.07 \pm 0.04^{\mathrm{a}}$ & $5.45 \pm 1.06^{\mathrm{b}}$ & $34.24 \pm 4.28^{\mathrm{a}}$ \\
200 & $38.50 \pm 1.31^{\mathrm{a}}$ & $0.20 \pm 0.22^{\mathrm{a}}$ & $6.91 \pm 0.26^{\mathrm{a}}$ & $43.36 \pm 3.87^{\mathrm{a}}$ \\
\hline
\end{tabular}

${ }^{1)}$ All values are mean $\pm \mathrm{SD}(\mathrm{n}=3)$.

${ }^{2}$ Different letters superscript indicate in the same column that means are significantly different $(p<0.05)$ by Duncan's test. 
값이 증가한다고 보고하였다. 앞선 연구결과와 달리 과열 증기건조 시간이 증가할수록 다래순의 $\mathrm{L}$ 값은 증가하였으 며, 이는 건조에 따른 수분증발로 인하여 전반적인 색이 밝아짐으로써 명도가 높아진 것으로 사료된다. 또한 갈변 도의 지표인 a 값의 증가는 갈변현상을 의미하며, 양의 a 값은 적색도를 나타내며 음의 a 값은 청색도를 나타낸다 (39). 따라서 200 초 건조한 다래순은 0.20 으로 양의 a 값을 가지므로 과도한 과열증기 건조는 다래순의 갈변현상을 유도하는 것으로 생각되어 적절한 처리 조건의 설정이 필요 할 것으로 사료된다.

\section{총 폴리페놀 및 플라보노이드 함량, 항산화 활성}

산채는 당과 결합한 배당체의 형태로 플라보노이드를 포함하여 폴리페놀 화합물이 다량 함유되어 있기 때문에 높은 항산화 특성으로 인한 다양한 기능성을 규명하고자 하는 연구가 활발히 진행되고 있다(3). 따라서 증기온도 $350^{\circ} \mathrm{C}$ 에서 과열증기처리 시간에 따른 다래순의 총 폴리페 놀 및 플라보노이드 함량, 항산화 활성을 측정하였고, 그 결과는 Table 3 과 같다. 건조 전 신선 다래순의 총 폴리페놀 함량은 $21.7 \mathrm{~g} \mathrm{GAE} / \mathrm{kg} \mathrm{DW}$, 총 플라보노이드 함량은 $13.9 \mathrm{~g}$ $\mathrm{RE} / \mathrm{kg} \mathrm{DW}$ 인 것으로 나타났다. Kwak과 Lee(1)의 연구결과 에 따르면 다래순의 총 폴리페놀 및 플라보노이드 함량은 각각 $33.0 \mathrm{mg}$ tannic acid/g dry w와 $29.3 \mathrm{mg}$ rutin/g DW인 것으로 보고하였다. 과열증기를 40-160초 처리한 다래순의 총 페놀 및 플라보노이드 함량은 유의적으로 증가하였으 며, 200초 처리 시 각각 $19.5 \mathrm{~g} \mathrm{GAE} / \mathrm{kg} \mathrm{DW}$ 와 $12.6 \mathrm{~g} \mathrm{RE} / \mathrm{kg}$ 으 로 급격하게 감소하는 것으로 나타났다. 다래순의 항산화 활성을 알아보기 위해 DPPH 라디컬 소거능, ABTS 라디컬 소거능, FRAP 환원력을 실시하였으며 총 페놀 및 플라보노 이드 함량 결과와 마찬가지로 160 초 처리 시간까지는 활성 이 증가했지만 200초 처리 시 활성이 크게 감소하는 것으로 나타났다. Lee 등(20)은 과열증기처리가 양파의 총 페놀 함량을 증가시키고 항산화 활성을 높여준다고 보고하였다.
Choi 등(41)은 열처리 시 식물 세포벽에 공유결합되어 있는 불용성 페놀성 화합물이 유리되어 용출이 용이해지기 때문 에 폴리페놀과 플라보노이드 화합물의 함량이 증가하고 이에 따라 항산화 활성이 높아지는 것으로 보고하였다. Kim 등(40)은 열처리 시 단백질과 결합된 고분자 페놀성 화합물이 저분자 화합물로 전환되어 총 폴리페놀 함량이 증가하는 반면 과열처리 시 탄화에 의해 함량이 감소한다고 보고하였다. Park 등(42)은 곤드레 나물을 열풍건조 처리 시 총 페놀 함량과 DPPH 라디컬 소거능이 감소하였으며 이는 열에 의해 페놀성분의 일부가 파괴되었기 때문이라고 보고하였다. Smogy와 $\operatorname{Luh}(43)$ 은 천일건조는 건조 과정 중 광화학 반응 및 산화반응으로 인해 피건조물이 변색되고 영양성분이 파괴되어 고품질의 제품 생산이 어렵다고 보고 하였으며, Holdsworth(44)은 열풍건조는 식품의 색상, 조직 감, 맛 및 영양가 저하 등의 문제점이 있다고 보고하였다. 즉 열처리 가공 중 영양소와 생리활성물질의 손실을 일으킬 수 있고, 과도한 열처리는 시료의 탄화와 일부 페놀성 화합 물의 파괴의 원인이 되어 항산화 활성을 감소시킬 수 있다 (40). 따라서 식품에 따라 최적의 과열증기 건조 온도 및 시간을 적용한다면 일반적으로 사용되는 천일건조와 열풍 건조의 문제점인 품질 및 영양적 특성 저하를 방지할 수 있을 것이라 생각된다. 또한 Kim 등(22)은 과열증기 처리는 현미의 lipoxygenase 불활성화에 매우 효과적이고, 과열증 기처리시간이 길수록 저장 후 산가가 낮은 것으로 나타나 과열증기는 저장성을 향상시킬 수 있는 가공방법이라고 보고하였다. 결과적으로 과열증기처리는 식품의 산화효소 를 불활성화하여 저장기간 동안의 산화반응을 억제할 수 있을 것이라 사료되며, 생리활성 측면에서 과열증기 처리 에 의해 영양성분과 항산화 활성을 최대로 높일 수 있는 160 초 처리 시간이 가장 적합한 것으로 생각된다.

\section{미생물 수 측정}

산채는 채취 시 토양과 물 등 자연환경에 의한 미생물이

Table 3. Total phenolic content, total flavonoid content, and antioxidant activities of Korean traditional actinidia leaves dried at oven temperature of $150^{\circ} \mathrm{C}$ and steam temperature of $350^{\circ} \mathrm{C}$ for $40-200 \mathrm{sec}$

\begin{tabular}{|c|c|c|c|c|c|}
\hline \multirow[b]{2}{*}{ Drying time (sec) } & \multirow[b]{2}{*}{$\begin{array}{l}\text { Total phenolic content } \\
(\mathrm{g} \mathrm{GAE} / \mathrm{kg})\end{array}$} & \multirow[b]{2}{*}{$\begin{array}{l}\text { Total flavonoid content } \\
\text { (g rutin/kg) }\end{array}$} & \multicolumn{3}{|c|}{ Antioxidant activity } \\
\hline & & & $\begin{array}{c}\text { DPPH radical scavenging } \\
\text { activity } \\
\text { (g BHAE } / \mathrm{Kg})\end{array}$ & $\begin{array}{c}\text { ABTS radical scavenging } \\
\text { activity } \\
\text { (g AAE } / \mathrm{Kg} \text { ) }\end{array}$ & $\begin{array}{l}\text { FRAP assay } \\
(\mathrm{g} \mathrm{Fe}(\amalg) / \mathrm{Kg})\end{array}$ \\
\hline Control & $21.71 \pm 0.05^{1 /(2)}$ & $13.86 \pm 0.16^{d}$ & $24.91 \pm 0.38^{\mathrm{b}}$ & $29.67 \pm 0.17^{\mathrm{b}}$ & $66.04 \pm 2.69^{c}$ \\
\hline 40 & $25.51 \pm 0.21^{b}$ & $15.22 \pm 0.66^{\mathrm{c}}$ & $25.67 \pm 0.05^{\mathrm{ab}}$ & $33.53 \pm 0.42^{\mathrm{a}}$ & $74.91 \pm 1.66^{b}$ \\
\hline 120 & $25.80 \pm 0.45^{\mathrm{ab}}$ & $17.84 \pm 0.94^{\mathrm{b}}$ & $26.02 \pm 0.05^{\mathrm{a}}$ & $32.31 \pm 0.14^{\mathrm{a}}$ & $75.96 \pm 0.72^{\mathrm{b}}$ \\
\hline 160 & $26.27 \pm 0.15^{\mathrm{a}}$ & $19.09 \pm 0.70^{\mathrm{a}}$ & $26.58 \pm 0.28^{\mathrm{a}}$ & $33.83 \pm 0.03^{\mathrm{a}}$ & $81.04 \pm 3.38^{\mathrm{a}}$ \\
\hline 200 & $19.53 \pm 0.11^{\mathrm{d}}$ & $12.58 \pm 0.71^{\mathrm{e}}$ & $24.69 \pm 1.05^{b}$ & $25.00 \pm 2.27^{\mathrm{c}}$ & $52.40 \pm 2.26^{\mathrm{d}}$ \\
\hline
\end{tabular}

\footnotetext{
${ }^{1)}$ All values are mean $\pm \mathrm{SD}(\mathrm{n}=3)$

${ }^{2)}$ Different letters superscript indicate in the same column that means are significantly different $(\mathrm{p}<0.05)$ by Duncan's test.
} 
부착되어 있으며 저장, 유통 보관단계에서 미생물이 급격 히 증식하거나 오염될 수 있어 이를 제어하는 방안이 필요 하다. 따라서 증기온도 $350^{\circ} \mathrm{C}$ 에서 과열증기처리 시간에 따 른 다래순의 일반세균 수와 대장균군 수를 분석하였고, 그 결과는 Table 4 와 같다. 대장균군은 모든 시료에서 검출되 지 않았으며, 대조군의 일반세균은 $2.58 \log \mathrm{CFU} / \mathrm{g}$ 으로 나 타났다. 과열증기를 40 초 처리한 다래순은 $2.48 \log \mathrm{CFU} / \mathrm{g}$ 으로 대조군에 비해 다소 감소하였지만 유의적 차이는 없었 고, 120 초 이상 처리한 다래순의 일반세균은 검출되지 않았 다. Park 등(21)은 $350^{\circ} \mathrm{C}$ 의 과열증기온도에서 1 분 동안 마늘 을 처리했을 때 일반세균이 $8.69 \log \mathrm{CFU} / \mathrm{g}$ 수준에서 2.92 $\log \mathrm{CFU} / \mathrm{g}$ 으로 감소했다고 보고하였다. Kim등(19)은 과열 증기건조가 열풍건조한 인삼분말보다 일반세균, 효모, 곰 팡이가 약 $2 \log$, 대장균군은 약 $1 \log$ 정도 더 감소하였으며, 이는 과열증기의 높은 온도에 의한 사멸로 판단된다고 보고 하였다. 일반적으로 산채류의 미생물을 제어하고 polyphenol oxidase나 peroxidase와 같은 산화 효소를 불활성화하기 위 해 건조 전처리로 blanching을 실시하지만 물리적 손상과 생리활성 물질의 손실 등의 문제점이 보고되고 있다 $(44,45)$. 과열증기처리는 다래순의 미생물 수의 감소에 효 과적이며 영양적 특성을 향상시킬 수 있어 blanching과 같 은 전처리 공정이 필요하지 않은 건조 방법으로 판단된다.

Table 4. The number of aerobic bacteria in Korean traditional actinidia leaves dried at oven temperature of $150^{\circ} \mathrm{C}$ and steam temperature of $350^{\circ} \mathrm{C}$ for $40-200 \mathrm{sec}$

\begin{tabular}{cc} 
& (unit: $\log \mathrm{CFU} / \mathrm{g}$ ) \\
\hline Drying time $(\mathrm{sec})$ & Aerobic bacteria \\
\hline Control & $2.58 \pm 0.27^{1 / \mathrm{a} 2)}$ \\
40 & $2.48 \pm 0.31^{\mathrm{a}}$ \\
120 & $\mathrm{ND}^{3)^{b}}$ \\
160 & $\mathrm{ND}^{\mathrm{b}}$ \\
200 & $\mathrm{ND}^{\mathrm{b}}$ \\
\hline
\end{tabular}

\footnotetext{
${ }^{1)}$ All values are mean \pm SD $(n=3)$.

${ }^{2)}$ Different superscript letters indicate that means are significantly different $(\mathrm{p}<0.05)$ by Duncan's test.

${ }^{3}$ Not detected.
}

\section{요 약}

본 연구는 과열증기처리 기술을 이용하여 산채류 중 하 나인 토종 다래순을 건조하였으며, $350^{\circ} \mathrm{C}$ 의 과열증기온도 에서 40-200초 처리 시간에 따라 수분함량 및 수분활성도와 그 상관관계를 분석하여 건조특성을 연구하였고, 이화학적 특성으로 색도, 총 폴리페놀 및 플라보노이드 함량, 항산화 활성과 미생물학적 특성으로 일반세균과 대장균군 수를 검사하였다. 처리 시간이 길어질수록 수분함량과 수분활성
도가 감소하였고 160 초 건조 시간 이후부터 건조된 상태의 다래순을 얻을 수 있었으며, 과열증기 처리에 따른 수분함 량과 수분활성도는 매우 높은 상관관계를 가졌다. 과열증 기처리 시간이 길어질수록 $\mathrm{L}, \mathrm{a}, \mathrm{b}$ 값과 색차값 $(\Delta \mathrm{E})$ 이 증가 하는 경향으로 나타났으며, 200 초 처리는 다래순의 갈변을 일으키는 것으로 나타났다. 다래순의 총 폴리페놀 및 플라 보노이드 함량, 항산화 활성은 160 초 처리 시간까지 점차적 으로 증가했지만 200초 처리 시 함량 및 활성이 급격하게 감소하는 것으로 나타났다. 대장균군은 모든 시료에서 검 출되지 않았으며, 일반세균의 경우 과열증기 120 초 처리 시간 이후부터 검출되지 않았다. 본 연구 결과와 같이 과열 증기 기술은 영양적·위생적으로 우수한 건조 토종 다래순 을 가공할 수 있을 것으로 판단되며, 이외에 여러 고품질의 건조 산채류 제조 시 기초자료로 활용될 수 있을 것이라 생각된다. 또한 과열증기처리는 다른 건조공정에 비해 단 시간에 식품을 건조할 수 있고 증발 증기를 재활용할 수 있어 경제적이고 산업적으로 활용 가치가 높은 건조방법으 로 생각되어 향후 이를 다양한 식품 가공·공정에 적용한 연구가 활발히 진행되어야 할 것으로 생각된다.

\section{감사의 글}

본 연구는 산림청 임업기술개발사업의 '다래를 활용한 건강 지향식품 소재 및 가공품 개발' 과제(과제번호: 2013자유 10)의 연구비 지원에 의해 수행되었으며 이에 감사드 립니다.

\section{References}

1. Kwak CS, Lee JH (2014) In vitro antioxidant and anti-inflammatory effects of ethanol extracts from sprout of evening primrose (Oenothera laciniata) and gooseberry (Actinidia arguta). J Korean Soc Food Sci Nutr, 43, 207-215

2. Je GY (2011) Eating Vegetables \& Eating Flowers Encyclopedia. Kim SI (Editor), Hyesung Press, Seoul, Korea, p 298-299

3. Lee SO, Lee HJ, Yu MH, Im HG, Lee IS (2005) Total polyphenol contents and antioxidant activities of methanol extracts from vegetables produced in Ullung island. Korean J Food Sci Technol, 37, 233-240

4. Jin DE, Park SK, Park CH, Seung TW, Choi SG, Heo HJ (2015) Nutritional components of Korean traditional actinidia (Actinidia arguta) sprout and in vitro antioxidant effect. Korean J Food Sci Technol, 47, 37-43 
5. Kim HJ, Park YJ, Cho JY, Chun SU, Seo YN, Heo BG (2007) Kinds and contents of the edible wild plants with anti-microbial, anti-oxidation, anti-cancer and anti-glycosuria activity shown in the domestic literature. J Korean Soc Peaple Plants Environ, 10, 44-69

6. Kim EM (2016) Processing materials of edible wild herbs and vegetables. Food Science and Industry, 49, 63-70

7. Kwon D, Kim GD, Kang W, Park JE, Kim SH, Choe E, Kim JI, Auh JH (2014) Pinoresinol diglucoside is screened as a putative a-glucosidase inhibiting compound in Actinidia arguta leaves. J Korean Soc Appl Biol Chem, 57, 473-479

8. Ahn HC, Chung LN, Choe EO (2015) In vitro antioxidant activity and a-glucosidase and pancreatic lipase inhibitory activities of several Korean Sanchae. Korean J Food Sci Technol, 47, 164-169

9. Lee AY, Kang MJ, Choe E, Kim JI (2015) Hypoglycemic and antioxidant effects of Daraesoon (Actinidia arguta shoot) in animal models of diabetes mellitus. Nutr Res Pract, 9, 262-267

10. Ahn H, Kim J, Kim J, Auh J, Choe E (2014) In vitro a-glucosidase and pancreatic lipase inhibitory activities and antioxidants of Samnamul (Aruncus dioicus) during rehydration and cooking. Food Sci Biotechnol, 23, 1287-1293

11. Rhim JW, Hwang KT (1995) Study on the drying characteristics of wild vegetables. Korean J Food Sci Technol, 27, 358-364

12. Hong JH, Lee WY (2004) Quality characteristics of osmotic dehydrated sweet pumpkin by different drying methods. J Korean Soc Food Sci Nutr, 33, 1573-1579

13. Youn KS (1998) Utilization of osmotic dehydration as pretreatment prior to drying. Korean J Postharvest Sci Technol, 5, 305-314

14. Litvin S, Mannheim CH, Miltz J (1998) Dehydration of carrots by a combination of freeze drying, microwave heating and air or vaccum drying. J Food Eng, 36, 103-111

15. Park SJ, Choi YB, Ko JR, Rha YA, Lee HY (2014) Effects of drying methods on the quality and physological activities of blueeberry (Vaccinium asher). Korean J Culinary Res, 20, 55-64

16. Yang ST (1997) Preparation of seasoned and semi-dried horse mackerel by cold air drying and quality of its product during partially frozen storage. Korean J Food Sci Technol, 29, 925-931

17. Kim OS, Lee DH, Chun WP (2008) Eco-friendly drying technology using superheated steam. Korean Chem Eng Res, 46, 258-273

18. Yoshida T, Hyodo T (1966) Superheated vapor speeds drying of foods. J Food Eng, 38, 86-87

19. Kim KT, Hong HD, Kim SS (2009) Quality characteristics of ginseng treated by hot air drying after being dried using super-heated steam. J Ginseng Res, 33, 361-366

20. Lee MH, Lee KY, Kim AN, Heo HJ, Kim HJ, Chun JY, Choi SG (2016) Effects of superheated steam treatment on volatile compounds and quality characteristics of onion. Korean J Food Preserv, 23, 369-377

21. Park CY, Lee KY, Kim AN, So SA, Rahman MS, Choi SG (2016) Physicochemical and microbial quality characteristics of garlic (Allium sativum L.) by superheated steam treatment. J Korean Soc Food Sci Nutr, 45, 1438-1446

22. Kim GR, Lee SH, Park JA, Shin JK (2016) Effect of superheated steam treatment on the rancidity of brown rice. Food Eng Prog, 20, 411-415

23. Choi SY, Choi JE, Cung YA, Lee YH, Lee JK (2016) Effect of superheated steam treatment on the production of unfried potato chips. Food Eng Prog, 20, 400-405

24. AOAC (1995) Official Methods of Analysis. $16^{\text {th }}$ ed, Association of Official Analytical Chemists, Washington DC, USA, $\mathrm{p} 1-45$

25. Hunter RS (1975) Scales for measurement of solour difference. In: The Measurements of Appearance, Hunter RS (Editor), Wiley, New York, NY, USA, p 133-140

26. Singleton VL, Rossi JA (1965) Colorimetry of total phenolics with phosphomolybdic - phosphotungstic acid reagents. Am J Enol Vitic, 16, 144-158

27. Chae SK, Kang GS, Ma SJ, Bang KW, Oh MW, Oh SH (2002) Standard Food Analysis. Jigu-moonwha Sa, Seoul, Korea, p 381-382

28. Blois MA (1958) Antioxidant determination by the use of a stable free radical. Nature, 181, 1199-1200

29. Re R, Pellegrini N, Proteggente A, Pannala A, Yangc M, Rice-Evans C (1999) Antioxidant activity applying an improved ABTS radical cation decolorization assay. Free Radical Bio Med, 26, 1231-1237

30. Benzie IFF, Strain JJ (1996) The ferric reducing ability of plasma (FRAP) as a measure of "antioxidant power": the FRAP assay. Anal Biochem, 239, 70-76

31. Chang KM (2007) Manufacturing of funtionalized color Mook by addition of the color and flavor from natural foods. Korean J Food Culture, 22, 365-372 
32. Koh HY, Kwon YJ (1989) Effect of storage temperature and humidity on water adsorption and rancidity of peanuts. J Korean Soc Food Nutr, 18, 216-222

33. Moreira RG (2001) Impingement drying of foods using hot air and superheated steam. J Food Eng, 49, 291-295

34. Dixon GM, Jen JJ (1997) Change of sugars and acids of osmovac-dried apple slices. J Food Sci, 42, 1126-1127

35. Chirife J, Zamora MC, Motto A (2006) The correlation between water activity and \% moisture in honey: Fundamental aspects and application to Argentine honeys. J Food Eng, 72, 287-292

36. Arslan D, Ozcan MM (2012) Evaluation of drying methods with respect to drying kinetics, mineral content, and color characteristics of savory leaves. Food Bioprocess Technol, 5, 983-991

37. Arslan D, Ozcan MM, Menges HO (2010) Evaluation of drying methods with respect to drying parameters, some nutritional and colour characteristics of peppermint (Mentha x piperita L.). Energy Convers Manage, 51, 2769-2775

38. Oh JH, Yoon S, Choi Y (2014) The effect of superheated steam cooking condition on physico-chemical and sensory characteristics of chicken breast fillets. Korean J Food Cook Sci, 30, 317-324

39. Erenturk S, Gulaboglu MS, Gultekin S (2005) The effects of cutting and drying medium on the vitamin $\mathrm{C}$ content of rosehip during drying. J Food Eng, 68, 513-518
40. Kim HY, Woo KS, Hwang IG, Lee YR, Jeong HS (2008) Effects of heat treatments on the antioxidant activities of fruits and vegetables. Korean J Food Sci Technol, 40, 166-170

41. Choi Y, Lee SM, Chun J, Lee HB, Lee J (2006) Influence of heat treatment on the antioxidant activities and polyphenolic compounds of Shiitake (Lentinus edodes) mushroom. Food Chem, 99, 381-387

42. Park SJ, Lee DW, Park SH, Rha YA (2016) Quality characteristics of Cirsium setidens Nakai by different drying method. Culi Sci Hos Res, 22, 104-114

43. Smogyi LP, Luh BS (1983) Vegetable dehydration. $2^{\text {nd }}$ ed, Luh BS, Woodroof JG (Editor), AVI Pub Co, Westpost, CT, USA, p 387-473

44. Holdsworth SD (1971) Dehydration of food products. J Food Technol, 6, 331-336

45. Kang JH, Park SM, Kim HG, Son HJ, Lee KY, Kang KN, Park JT, Song KB (2016) Combined treatment of aqueous chlorine dioxide, organic acid, and blanching for microbial decontamination of wild vegetables after harvest. J Korean Soc Food Sci Nutr, 45, 277-283

46. Kim MH, Jnag HL, Yoon KY (2012) Changes in physicochemical properties of Haetsun vegetables by blanching. J Korean Soc Food Sci Nutr, 41, 647-654 